\title{
Variability in Macadamia integrifolia by RAPD markers
}

\author{
Nelson Barbosa Machado Neto ${ }^{1 *}$ and Adriano Takashi Moryia ${ }^{1}$
}

Received 27 October 2009

Accepted 22 March 2010

\begin{abstract}
Macadamia is one of the most valuable commercial nuts and its culture is a good alternative for small farmers or for large properties with a low capacity for the mechanization of its areas. Macadamia clones, due to their morphological proximity exhibited some difficulties in field identification that could difficult the right plant distribution. The objective of this work was to genetically characterize, by RAPD markers, different macadamia clones under cultivation. Leaves from 'HAES-741', 'HAES-660', 'IAC-920BX', 'IAC-920', 'HAES-344', 'IAC-420', 'HAES-816', 'IAC-1.21', 'Shimada', 'IAC - Campinas B', 'IAC - Campinas A' and 'HAES-Aloha' were donated by Queen Nut Macadâmia. DNA was extracted and amplified with 15 primers and the binary data (presence/absence of bands) collected was used and dendrograms constructed. Clone identification, via RAPD was possible using primers Op G18, C19 and C7. Most of the genetic variation is inside the Brazilian or Hawaiian groups rather than between the groups and could allow inbreeding or croxssing between distant clones.
\end{abstract}

Key words: Nut, clone identification, DNA.

\section{INTRODUCTION}

The macadamia tree belongs to Proteaceae, the same botanical family as Grevillea. Originating in Australia, it was introduced to Hawaii in 1878 and to Brazil in 1931. Actually there were 10 known species, but just three were used as food (Macadamia integrifolia, Macadamia tetraphyla and Macadamia ternifolia). Culture expansion occurred from the 80's, precisely to the beginning of the 90's. It found good growing conditions in South America, from Bahia (NE, Brazil) to Uruguay. It is one of the most lucrative cultures in value per area. As a recent culture in Brazil, the information about the culture and the recommended technologies has initially been based on the research results of Australia and Hawaii (Sacramento 2003). Since 1940 IAC (Instituto Agronômico de Campinas) started a process of selection and culture conduction in the local conditions (Sobierjaski et al. 2006).

The need for genetic resources in agriculture implies that there is an increase of modern methods and bio techniques to reach success in sustainable agriculture, and from these processes molecular markers have been used (Vilela-Morales and Valois 2000). Morphological markers have a narrow availability for some cultures for which the number of molecular markers is higher as for example in corn, peas and tomato (Ferreira and Grattapaglia 1998).

Many molecular biology techniques are available today for variability detection at DNA level, e.g., for genetic polymorphism evaluation (Lima 2003). These techniques allow, virtually, an unlimited number of molecular markers that can search the whole genome of the organism in study (Borba 2007). PCR technology was developed in the 80's

\footnotetext{
${ }^{1}$ UNOESTE, Campus II, Faculdade de Ciências Agrárias, Rodovia Raposo Tavares, km 572, Limoeiro, 19.067-175, Presidente Prudente, SP, Brazil. *E-mail: nbmneto@unoeste.br.
} 
causing a revolution in the basic biological research that allowed the understanding of areas of breeding, as well as very high number of specific DNA fragments which are visible in a electrophoresis gel with specific dyes (Ferreira and Grattapaglia 1998).

Molecular markers could define precisely the fingerprint of any organism, and in the case of plants it is important to plant protection and to follow the offspring, which allows acceleration and facilitates the processes of selection and the recombination of superior individuals (Salla 2002).

Among the markers available today, the detection of RAPD (Random Amplified Polymorphic DNA) markers is distinct for its simplicity, fast execution, low cost, the small quantity of DNA necessary, and the possibility of the study of species for which molecular information is scarce (Williams et al. 1990). RAPD has been used for different numbers of species, independent of the strategy of reproduction with success, like in Citrus (allogamous, Oliveira et al. 2000, Oliveira et al. 2001), Passiflora (allogamous, Crochemore et al. 2003), Coffea (autogamous, Diniz et al. 2005; allogamous, Ferrão et al. 2008), Aspidosperma (allogamous, Torezan et al. 2005) and Zea mays (self-fertilized, Souza et al. 2008). The aim of this work was to study the genetic similarity among germplasm accessions of twelve clones of Macadamia from two selection groups, Hawaiian and Brazilian, to check the proximity of them with the germplasm analysed, through the use of RAPD markers.

\section{MATERIAL AND METHODS}

The experiment was conducted at UNOESTE's laboratory of Molecular Genetics and Cytogenetics in Presidente Prudente, SP. For DNA extraction, the method described by Doyle and Doyle (1987) was used, with modifications. The leaf tissue of twelve clones of Macadamia integrifolia 'HAES-741', 'HAES-660', 'HAES344', 'HAES-816' and 'HAES-Aloha' constituting the Hawaiian group and 'IAC-420', 'IAC-920 BX', 'IAC-920', 'IAC-1.21', 'Shimada', 'IAC-Campinas B', 'IAC-Campinas A' as the Brazilian group were used.

Tissue was ground in a mortar with a pestle under liquid nitrogen. Buffer composed of Tris-EDTA pH 8.0, $500 \mathrm{mM}$ CTAB and $2 \%$ ß-mercaptoethanol at $65^{\circ} \mathrm{C}$ at a 1:10 ratio (w:v) was added to the powder, and the mix was incubated at that temperature for $40 \mathrm{~min}$. After that, chloroform:isoamyl alcohol (24:1) was added and mixed carefully for $10 \mathrm{~min}$. The mixture was centrifuged at
12,000 Xg for $15 \mathrm{~min}$. The aqueous phase was collected and cooled in an ice bath. $7.5 \mathrm{M}$ ammonium acetate and isopropyl alcohol were added to a final concentration of $6 \%$ and $54 \%$, respectively. The mixture was placed at $-20^{\circ} \mathrm{C}$, $24 \mathrm{~h}$. A new cycle of centrifugation was done and the liquid phase discarded. Pellets were washed twice with 70\% ethanol at $65{ }^{\circ} \mathrm{C}$, one minute each and air-dried in an air flow cabinet. DNA was dissolved in a TE buffer, $\mathrm{pH}$ 8.0, and quantified by a spectrophotometer at 260/280 nm and adjusted to $10 \mu \mathrm{g} \cdot \mu \mathrm{L}^{-1}$.

Amplifications were done as in Williams et al. (1990), with modifications. Genomic DNA was amplified in a reaction volume of $25 \mu \mathrm{L}$ containing $10 \%$ of Tris KCl buffer (20 mM Tris-HCl, pH 8.4 and $50 \mathrm{mM} \mathrm{KCl}$ ), $1.5 \mathrm{mM} \mathrm{MgCl}_{2}$, $0.4 \mu \mathrm{M}$ of primer, $0.2 \mu \mathrm{M}$ of each dNTP, one Taq unit and template DNA (25 and $50 \mathrm{ng}$ ). RAPD amplifications were performed in a thermocycler with the following steps: $94^{\circ} \mathrm{C}$, three minutes for initial denaturation, followed by 43 cycles of one min at $94^{\circ} \mathrm{C}$, one min at $37^{\circ} \mathrm{C}$ for primer annealing and $30 \mathrm{~s}$ at $72{ }^{\circ} \mathrm{C}$ for chain elongation. One extra step of five minutes at $72{ }^{\circ} \mathrm{C}$ was done at the end for a final elongation. Only bands present in amplifications of both 25 and $50 \mathrm{ng}$ of template DNA were considered. One hundred twenty Operon primers, series A, B, D, G, X and Y, were evaluated. Amplification products were separated by gel electrophoresis in a $1.5 \%$ agarose gel with $1 / 2 \mathrm{X}$ TBE buffer. The gel was stained with ethidium bromide and pictures were captured by a CCD machine (Alpha-Inmotech) and by ChemiImager software.

Bands were used to construct a similarity matrix based on the Jaccard coefficient, coding 1 as present and 0 as absent. The grouping analysis was done using the UPGMA algorithm (Unweighted Pair-Group Method Using an Arithmetic Average). This analysis was performed with the software Gene (Cruz 2006). Molecular variance analysis (AMOVA) was calculated by total decomposition of its components among and between accessions using the square distances (Excoffier et al. 1992) with the software Arlequim (Excoffier et al. 2006).

\section{RESULTS AND DISCUSSION}

The 12 samples of the Macadamia integrifolia were amplified with the 15 selected primers, generating 130 bands with an average of 8.7 bands per primer, all of them polymorphic. The fragment size ranged from 300 to $1550 \mathrm{bp}$ (Table 1). The number of bands according to Telles et al. (2001) is more important than the primer number, an idea 
Table 1. Nucleotide sequences, number of bands and number of polymorphic bands of each primer used for RAPD-PCR analysis of Macadamia integrifolia

\begin{tabular}{cccccc}
\hline Primers & $\begin{array}{c}\text { Nucleotide } \\
\text { sequence } \\
\left(\mathbf{5}^{\prime} \rightarrow \mathbf{3}^{\mathbf{3}}\right)\end{array}$ & $\begin{array}{c}\text { Number of } \\
\text { bands }\end{array}$ & $\begin{array}{c}\text { Polymorphic } \\
\text { bands }\end{array}$ & $\begin{array}{c}\text { Polymorphism } \\
\mathbf{( \% )}\end{array}$ & $\begin{array}{c}\text { Fragment size } \\
\mathbf{( p b )}\end{array}$ \\
\hline C7 & GTCCCGACGA & 12.0 & 11.0 & 91.7 & $320-1520$ \\
C9 & CTCACCGTCC & 8.0 & 4.0 & 50.0 & $300-1260$ \\
C19 & GTTGCCAGCC & 11.0 & 10.0 & 90.9 & $350-1340$ \\
D8 & GTGTGCCCCA & 6.0 & 4.0 & 66.7 & $530-1420$ \\
G5 & CTGAGACGGA & 12.0 & 11.0 & 91.7 & $310-1460$ \\
G7 & GAACCTGCGG & 8.0 & 8.0 & 100.0 & $500-1350$ \\
G11 & TGCCCGTCGT & 7.0 & 6.0 & 85.7 & $340-1180$ \\
G17 & ACGACCGACA & 7.0 & 7.0 & 100.0 & $360-1110$ \\
G18 & GGCTCATGTG & 13.0 & 13.0 & 100.0 & $310-1480$ \\
X8 & CAGGGGTGGA & 7.0 & 5.0 & 71.4 & $350-1550$ \\
X11 & GGAGCCTCAG & 6.0 & 5.0 & 83.3 & $540-1190$ \\
X20 & CCCAGCTAGA & 7.0 & 7.0 & 100.0 & $340-1120$ \\
Y6 & AAGGCTCACC & 6.0 & 5.0 & 83.3 & $310-1210$ \\
Y9 & AGCAGCGCAC & 8.0 & 8.0 & 100.0 & $360-1530$ \\
Y14 & AGCCGTGGAA & 12.0 & 12.0 & 100.0 & $300-1370$ \\
\hline Average & & 8.7 & 7.7 & 87.6 & \\
Total & & 130.0 & 116.0 & & \\
\hline
\end{tabular}

that is in accordance with several authors regarding genetic estimates by the RAPD technique. Dias et al. (2004) argued that the better results for RAPD use may be done, according the literature, with at least 160 bands. In this case, 130 bands were found (Table 1) with good polymorphism (89\%) and with bands clearly visible and with high reproducibility, because they were amplified by two different DNA concentrations (25 and $50 \mathrm{ng}$ ).

Allogamous species, by definition, are much more variable than autogamous (Yanaka et al. 2005). Macadamia, as an allogamous, in the majority of the species, is cross pollinated, in this case by animals (hummingbirds, bees and butterflies). In some allogamous species such as Aspidosperma (Torezan et al. 2005), Medicago sativa (Crochemore et al. 1996), Bromus inermis and B. riparius (Ferdinandez and Coulman 2002) variability among populations is higher than within population. In Lolium multiflorum, these values can reach 98\% within populations (Vieira et al. 2004), which consequently reduce the possibilities of genetic drift and endogamy contributing to the maintenance of high diversity inside the species.

In this study, Macadamia clones from different plant breeding programs were grouped together in the branches of the tree (Figure 1). Since this species is distributed in a large area with complex environments, its gene-flow is rich within the species. Even in the case of high genetic similarity between two clones ('HAES-344' and 'IAC-420').

$\mathrm{F}_{\mathrm{ST}}$ estimates the gene flow between two populations or species, where low values indicate introgression between populations and consequently high genetic variability. On the other hand, a low gene flow leads to high $\mathrm{F}_{\mathrm{ST}}$ values

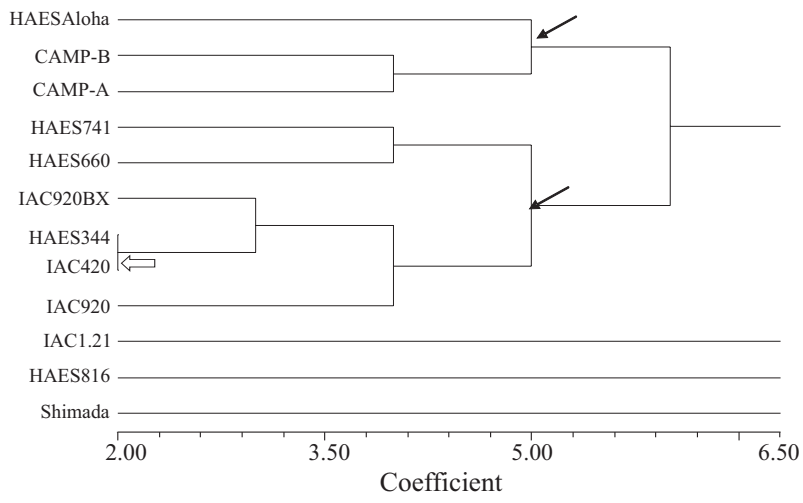

Figure 1. Similarity among accesses of macadamia estimated by 15 RAPD primers.

indicating that populations became endogamic and consequently, for alogamous species, more vulnerable to gene erosion. In this case, the Fst values are low indicating a very high variability in the suited clones (Table 2). For plants grouped as Brazilian, this value is lower than the average or than the Hawaiian group. It means that there were variabilities to be exploited especially if clones as 'IAC-Campinas A or B' would be crossed with 'Shimada' or 'IAC-1.21', which could maintain a high variability and improve some qualities in the offspring. The crosses between 'IAC-Campinas A' x 'IAC-Campinas B', 'IAC-920' x 'IAC-420', 'IAC-420’ x ‘IAC-920BX'or 'IAC-920’ x ‘IAC920BX' could also be done with the expectation of good genetic gain, by fixing some characters. In our case, $\mathrm{F}_{\mathrm{ST}}$ for all samples (0.0328) and its sub samples (Hawaiian 0.0439 and Brazillian 0.0249) shows that there was a high gene flow among all samples, which could be used in favor of plant breeding programs (Table 2).

Table 2. Wright's measurement of population differentiation (FsT) using RAPD markers between groups in Macadamia integrifolia

\begin{tabular}{lccc}
\hline Group & F $_{\text {ST }}$ & Numbers of samples & $\begin{array}{c}\text { Polymorphic band in the } \\
\text { group }\end{array}$ \\
\hline Hawaiian & 0.0439 & 5 & 75 \\
Brazilian & 0.0249 & 7 & 94 \\
\hline Average & 0.0328 & 12 & \\
\hline
\end{tabular}

It is well known that domestication strongly reduces sequence diversity in genes controlling traits of interest (Allard 1988, Wang et al. 1999, Salamini et al. 2002). In populations submitted to constant selection, where just the superior individuals were promoted for reproduction, the alleles controlling characters of interest had their frequency increased; leading to diversity loss in crop plants (Salamini et al. 2002). It is also well documented that although 
most domestication traits are quantitatively controlled, the dramatic morphological changes that accompanied domestication may be due to relatively few genes (Koinange et al. 1996). The decrease in genetic variability that is detected in populations due to driven selection (Wang et al. 1999) was not found in this work.

The OP G18 primer (Figure 2) isolated the clones 'HAES-741', 'IAC-920BX', 'IAC-920', 'HAES-816', 'HAES660' and 'IAC-420'. The primer Op C19 (Figure 2) isolated the clone 'HAES-344' and put it into four pairs and the others into one trio, and the primer Op C7 (Figure 2) did not isolate any of the 12 clones. However, using the combination of two primers together the clones 'HAESAloha', 'Shimada', 'IAC-1.21', 'Campinas B' and 'Campinas A' were isolated. The clone 'Shimada' could be identified using the primer G18 and C7. In the tree generated by the C7, this clone is combined with 'HAES-660', which, by its turn, is isolated in the G18. For 'Campinas B' and 'IAC1.21 ' the primer combination is G18 and C19. In the G18 'Campinas B' is combined with 'IAC-1.21' and in C19 with the clone 'HAES-816'. However, 'HAES-816' is alone in the tree of the G18 primer. 'IAC-1.21' is combined with 'HAES-741' in the primer C19, but this one is alone in the G18. The identification of 'Campinas A' could be done by combining C19 and C7 primers. In the C7 this clone is grouped with 'HAES-344', however in C19 this one is isolated. 'HAES-Aloha' could be identified by two combinations either with C7 and C19 or with C7 and G18, but the first is the easiest. In primer C19 this clone is combined with 'Campinas A', but in the C7 primer this clone comes with 'IAC-1.21'. These three primers allowed the distinction of the twelve clones of Macadamia integrifolia, easily, by the isolation of seven cultivars and by combination of two primers that exhibited the difference between the last five (Figure 2). Variability in Macadamia integrifolia is high enough to permit inbreeding and selection among clones. Three of the fifteen primers used allowed the identification of the twelve Macadamia clones.

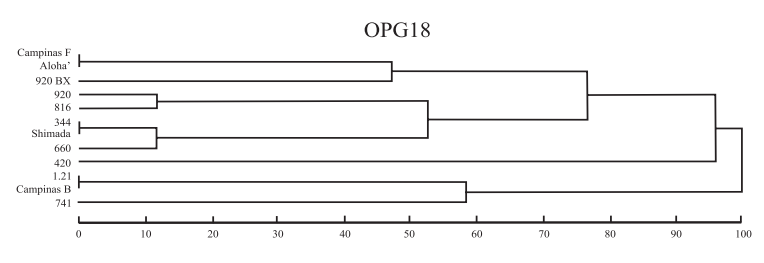

OPC19

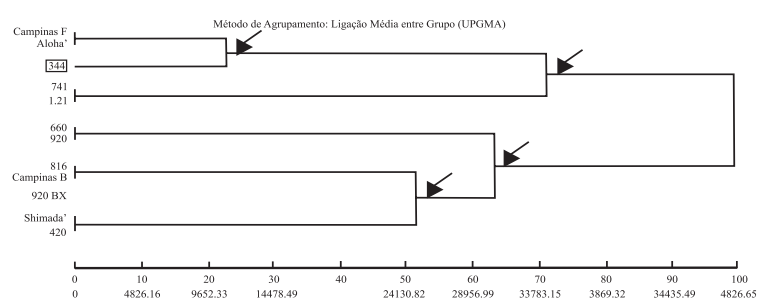

OPC7

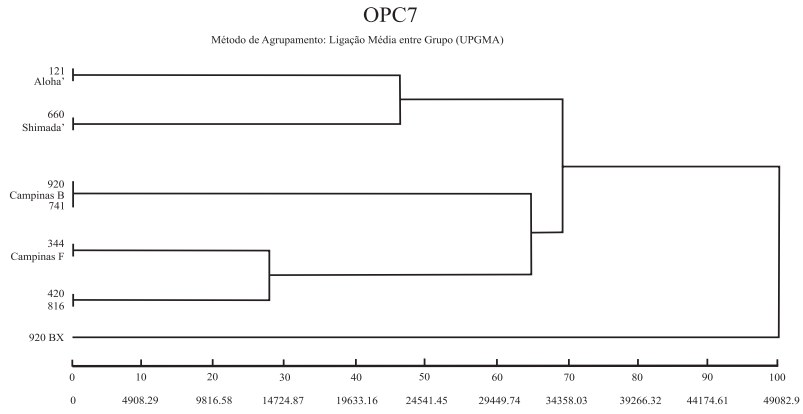

Figure 2. UPGMA tree based on primer of Macadamia integrifolia accessions.

\section{Variabilidade em Macadamia integrifolia por marcadores RAPD}

RESUMO - A Macadamia é uma das mais valiosas nozes e sua cultura é uma boa alternativa para pequenos agricultores ou grandes propriedades com pouca capacidade de mecanização. Devido à semelhança morfológica, existem algumas dificuldades de identificação, o que poderia atrapalhar a correta distribuição destes. O objetivo deste trabalho foi caracterizar geneticamente, por meio de marcadores RAPD, diferentes clones. Folhas dos clones 'HAES-741', 'HAES-660', 'IAC-920BX', 'IAC-920', 'HAES-344', 'IAC-420', 'HAES-816', 'IAC-1.21', 'Shimada', 'IAC - Campinas B', 'IAC - Campinas A' e 'HAES-Aloha' foram cedidas pela Queen Nut Macadâmia. O DNA foi extraído e amplificado com 15 primers e os dados binários (presença/ausência de bandas) obtidos foram analisados e os dendrogramas construídos. Identificação Clonal, por meio de RAPD, foi possível utilizando-se os primers Op G18, C19 e C7. A maior parte da variação genética está dentro dos grupos Brasileiro ou Havaiano do que entre grupos, permitindo tanto endogamia como cruzamento entre clones distintos.

Palavras-chave: Nozes, identificação clonal, DNA. 


\section{REFERENCES}

Allard RW (1988) Genetic changes associated with the evolution of adaptedness in cultivated plants and their wild progenitors. Journal of Heredity 79: 225-238.

Crochemore ML, Huyghe C, Kerlan MC, Durand F and Julier B (1996) Partitioning and distribution of RAPD variation in a set of populations of the Medicago sativa complex. Agronomie 16: 421-432.

Crochemore ML, Molinari HBC and Vieira LGE (2003) Genetic diversity in passion fruit (Passiflora spp.) evaluated by RAPD markers. Brazilian Archives of Biology and Technology 46: $521-527$.

Cruz CD (2006) Programa Genes: análise multivariada e simulação. Editora UFV, Viçosa, 175p.

Dias LAS, Picoli EAT, Rocha RB and Alfenas AC (2004) A priori choice of hybrid parents in plants. Genetics and Molecular Research 3: 356-368

Diniz LEC, Ruas CF, Carvalho NP, Torres FM, Ruas EA, Santos MO, Sera T and Ruas PM (2005) Genetic diversity among forty coffee varieties assessed by RAPD Markers associated with restriction digestion. Brazilian Archives of Biology and Technology 48: 511-521.

Doyle JJ and Doyle JL (1987) A rapid DNA isolation method for small quantities of fresh tissues. Phytochemistry Bulletin of the Botanical Society of America 19: 11-15.

Excoffier L, Smouse PE and Quattro JM (1992) Analysis of molecular variance inferred from metric distances among DNA haplotypes: application to human mitochondrial DNA restriction data. Genetics 131: 479-491.

Excoffier L, Laval G and Schneider S (2006) Arlequin ver. 3.0: An integrated software package for population genetics data analysis. Evolutionary Bioinformatics Online 1: 47-50

Ferdinandez YSN and Coulman BE (2002) Evaluating genetic variation and relationships among two bromegrass species and their hybrid using RAPD and AFLP markers. Euphytica 125: 281-291.

Ferrão MAG, Fonseca AFA, Ferrão RG, Barbosa WM and Souza EMR (2009) Genetic divergence in conillon coffee revealed by RAPD markers. Crop Breeding and Applied Biotechnology 9: 67-74.

Ferreira ME and Grattapaglia D (1998) Introdução ao uso de marcadores moleculares em análise genética. 3nd ed. Embrapa Cenargen, Brasília, 220p.

Koinange EMK, Singh SP and Gepts P (1996) Genetic control of the domestication syndrome in common bean. Crop Science 36: 1037-1045.

Lima MR, Augustin E, Choer E and Raseira MCB (2003) Caracterização de cultivares de pessegueiro e de nectarineira por marcadores moleculares. Pesquisa Agropecuária Brasileira 38: 349-355.

Oliveira RP, Cristofani M and Machado MA (2001) Marcadores RAPD para mapeamento genético e seleção de híbridos de Citrus. Revista Brasileira de Fruticultura 23: 477-481.
Oliveira RP, Novell VM and Machado M (2000) A freqüência de híbridos em cruzamentos entre tangerina 'Cravo' e laranja 'Pera’: análise de marcadores morfológicos e RAPD. Pesquisa Agropecuária Brasileira 35: 1895-1903.

Sacramento CK and Pereira FM (2003) Fenologia da floração da nogueira macadâmia (Macadamia integrifolia Maiden \& Betche) nas condições climáticas de Jaboticabal, São Paulo, Brasil. Revista Brasileira de Fruticultura 25: 19-22.

Salamini F, Özkan H, Brandolini A, Schäfer-Pregl R and Martin W (2002) Genetics and geography of wild cereal domestication in the near east. Nature: Review of Genetics 3: 429-441.

Salla MFS, Ruas CF, Ruas PM and Carpentieri-Pípolo V (2002) Uso de marcadores moleculares na análise da variabilidade genética em acerola (Malpighia emarginata D.C.). Revista Brasileira de Fruticultura 24: 15-22.

Sobierajski GR, Francisco VLFS, Rocha P, Ghilardi AA and Maia ML (2006) Noz Macadâmia: produção, mercado e situação no estado de São Paulo. Informações Econômicas 36: 25-36.

Souza SGH, Carpentieri-Pipolo V, Ruas CF, Carvalho VP, Ruas PM and Gerage AC (2008) Comparative analysis of genetic diversity among the maize inbred lines (Zea mays $L$.) obtained by RAPD and SSR markers. Brazilian Archives of Biology and Technology 51: 183-192.

Telles MPC, Monteiro MSP, Rodrigues FM, Soares TN, Resende LV, Amaral AG and Marra PR (2001) Marcadores RAPD na análise de divergência genética entre raças de bovinos e número de loci necessários para a estabilidade da divergência estimada. Ciência Animal Brasileira 2: 87-95.

Torezan JMD Souza RF, Ruas PM, Ruas CF, Camargo EH and Vanzeca ALL (2005) Genetic variability of pre and postfragmentation cohorts of Aspidosperma polyneuron Muell. Arg. (Apocynaceae). Brazilian Archives of Biology and Technology 48: 171-180.

Vieira EA, Castro CM, Oliveira AC, Carvalho FIF, Zimmer PD and Martins LF (2004) Genetics structure of annual ryegrass (Lolium multiflorum) populations estimated by RAPD. Scientia Agricola 61: 407-413.

Vilela-Morales E and Valois ACC (2000) Recursos genéticos vegetais autóctones e seus usos no desenvolvimento sustentável. Cadernos de Ciência \& Tecnologia 17: 11-42.

Wang RL, Stec, Hey AJ, Lukens L and Doebley J (1999) The limits of selection during maize domestication. Nature 398: 236239.

Williams JGK, Kubelik AR, Livak KJ, Rafalski JA and Tingey SV (1990) DNA polymorphisms amplified by arbitrary primers are useful as genetic markers. Nucleic Acids Research 18: 6531-6535.

Yanaka YF, Dall’Agnol M, Schifino-Wittmann MT, Dias PMB and Gomes KE (2005) Variabilidade genética em populações naturais de Bromus auleticus Trin. ex Nees (Poaceae) com base em isoenzimas e marcadores RAPD. Revista Brasileira de Zootecnia 34: 1897-1904. 